Conference Paper

\title{
Optimization of Annual and Five Years Tax Payment Services for Mo- torized Vehicles in Samsat "X"
}

\author{
Yustina Ngatilah ${ }^{1 *}$, Siati ${ }^{1}$, Caecilia Pujiastuti ${ }^{2}$ \\ ${ }^{1}$ Industrial Engineering Department, Universitas Pembangunan Nasional “Veteran” Surabaya, East Java, \\ Indonesia. \\ ${ }^{2}$ Chemical Engineering Department, Universitas Pembangunan Nasional “Veteran” Surabaya, East Java, \\ Indonesia.
}

*Corresponding author:

E-mail:

yustinangatilah@gmail.com

\begin{abstract}
The Samsat "X" office is a joint service office between the police, the regional income office, and the Jasa Raharja. The services provided are annual and five years of tax payments for motorized vehicles. The current service process is having an uncertain or probabilistic service time and long waiting time, resulting in long queues. This long queue condition causes taxpayer dissatisfaction. One of the methods to solve this problem is the Monte Carlo simulation. Monte Carlo simulation is a simulation method for solving problems with a set of sampling techniques from a probabilistic process. The objective of this research is to determine the optimum number of service personnel by using the Monte Carlo simulation method. The results of this simulation are the optimum conditions (best) for the tax payment services problem at the Samsat "X" office. The result shows that the optimum conditions are obtained with an average waiting time $=22.5479$ minutes, an average of service utility level $=81.23 \%$, queue length $=3$ persons, and the number of service personnel $=$ 3 persons for annual tax payment services, while for five years tax payment services, the optimum condition for average waiting time $=42.85336$ minutes, an average of service utility level $=91.38 \%$, queue length $=5$ persons, and the number of service personnel 2 persons.
\end{abstract}

Keywords: waiting for time, service utility level, queue length, Monte Carlo simulation

\section{Introduction}

Every motorized vehicle owner is required to pay taxes, both annual and five years taxes. Payment of motorized vehicle taxes is served by the Samsat office, which is an integrated combination of services between the police, the regional revenue office, and the Jasa Raharja. For Motorized vehicle tax payment services at the Samsat "X" office, there are often found the occurrence of uncertain or probabilistic service times and long waiting times, resulting in long queues. This results in the dissatisfaction of motorized vehicle taxpayers.

The queue for tax payment services in Samsat " $X$ " is divided into two, namely annual and five years tax payments. The annual taxpayers must go through three stages of service, namely the registration, the approval, and the payment. Five years taxpayers must first go through the registration and physical check processes, then payment and continue to the plate printing process. This tax payment services are included in the type of single queue-double service (single channel multi-phase) (Mulyono, 2017).

\section{How to cite:}

Ngatilah, Y., Siati, \& Pujiastuti, C. (2020). Optimization of annual and five years tax payment services for monoterized

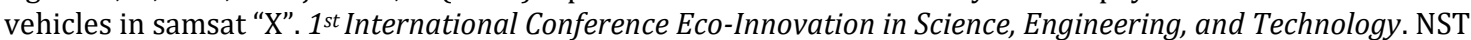

Proceedings. pages 189-195. doi: 10.11594/nstp.2020.0529 


\section{$\rightarrow \mathrm{OOOO} \rightarrow \underset{\text { Server }}{\mathrm{O}} \rightarrow \underset{\text { Server }}{\mathrm{O}} \rightarrow$}

The service queuing discipline used is First Come first Out (FIFO), the first coming is the first to be served (Ariyani, 2010). The condition of service time, waiting time, and queue length in the question is uncertain/probabilistic, so the suitable method for solving this problem is Monte Carlo simulation (Blackstone et al., 1989). Monte Carlo simulation is defined as a statistical sampling technique used to estimate the solutions of quantitative problems (Fadjar, 2008). Monte Carlo simulations allow the managers to determine how various policies or organizational conditions will be modified by random influence behavior (researcher/observer) (Tersine, 1988).

The following are the steps that must be done in a Monte Carlo simulation:

1. Construct probability distributions of the key variables/arrival time and service time.

One common way to construct the probability distributions for a variable is to take the past results into account. The probability or relative frequency for each output of each variable is determined by dividing the observed frequency by the total number of observations. Arrival patterns and service times are randomly distributed which are Poisson and Exponential (Ginting, 2014; Magdalena, 2011).

2. Converting the frequency distribution into a cumulative probabilistic distribution.

The conversion from ordinary probabilistic distribution to cumulative probabilistic distribution is done by adding up each possible number with the previous number. These cumulative probabilities can be used to help assign random values.

3. Taking a random sample from the cumulative distribution to determine the value of a specific variable to be used in the simulation.

The method used to take samples is to use a random number table. Random numbers are entered into the cumulative probabilistic distribution to produce specific variable values. The sequence of random numbers used will replace the pattern of the expected variance.

4. Simulate operations in the number of replications.

The results of the experiment can be simulated simply by selecting random numbers from a random number table.

The formulas used to calculate the waiting time, queue length, and service utility in the simulation are as follows (Law et al., 2000):

1. Delay

$\hat{d}(n)=\frac{\sum_{i=1}^{n} D i}{n}$

with:

$\hat{d}(n)=$ average waiting time in the queue

$\mathrm{Di} \quad=$ customer waiting time

$\mathrm{N} \quad=$ the number of customers served during the simulation

2. Average queue length per unit of time

$\hat{q}(n)=\frac{\int_{0}^{T(n)} Q(t) d t}{T(n)}$

with:

$\hat{q}(n)=$ average number of customers in the queue

$\mathrm{Q}(\mathrm{t})=$ the number of customers waiting in line 
$\mathrm{T}(\mathrm{n})$ = long service time interval

3. Server Utility

$$
\mu(n)=\frac{\int_{0}^{T(n)} B(t) d t}{T(n)}
$$

with:

$\mu(n)=$ Server utility

$B(t)$ = Service busy function

An arena is a software that is suitable for solving simulation problems with various circumstances or scenarios. The modules will be used in research when using the Arena software to simulate the implemented information system. Some general flowchart modules that need to be known are as follows (Kelton et al., 1998):

1. Create Module: This module is used when an entity starts in the simulation module.

2. Dispose Module: This module is the endpoint of the entities in the simulation model.

3. Process Module: This module is the main process method in simulation. The option of using resources is available in this module. It includes the option of using a sub-model and specifying hierarchical logic.

4. Decide Module: This module shows the decision-making process in a system if there are certain conditions.

Batch Module, Separate Module, Assign Module, and Record Module

\section{Research Method}

Research steps:

1. Data collection of arrival time, service start time, and service completion time of each taxpayer.

2. Data Processing

The steps taken in data processing are:

a. Determination of the probabilistic distribution

b. Determination of the cumulative distribution

c. Generating random numbers

d. Queue simulation with Arena software for initial model based on the real situation

e. Simulation of the proposed model for improving the queuing system (by changing the number of the server)

3. Results and Discussion

Discussing the suitability of the simulation results from the proposed improvement with the owner's policy of the service queue system, in this case, Samsat, in which the policy has a maximum waiting time of 45 minutes for taxpayers, so the proposed improvement of the service queue system that meets the policy is selected.

4. Conclusions and Suggestions

From the results of the discussion, the condition for the best queuing service system in this research is concluded

\section{Result and Discussion}

\section{Data Collection}

Data collection was carried out by direct observation. The data collected are Customer data from 2nd January 2019 until 31st January 2019, time of arrival, service start time, and service finished time both for annual and five years tax payment. 
Table 1. Observation data for time of arrival, service start time, and service finished time of annual tax payments

\begin{tabular}{|c|c|c|c|c|c|c|c|c|}
\hline Date & Customer & $\begin{array}{l}\text { Time of ar- } \\
\text { rival }\end{array}$ & $\begin{array}{l}\text { The service } \\
\text { start time of } \\
\text { registration }\end{array}$ & $\begin{array}{l}\text { Time fin- } \\
\text { ished being } \\
\text { served reg- } \\
\text { istration }\end{array}$ & $\begin{array}{c}\text { The service } \\
\text { start time of } \\
\text { endorse- } \\
\text { ment }\end{array}$ & $\begin{array}{c}\text { Time fin- } \\
\text { ished being } \\
\text { served of } \\
\text { endorse- } \\
\text { ment } \\
\end{array}$ & $\begin{array}{c}\text { The service } \\
\text { start time of } \\
\text { payment }\end{array}$ & $\begin{array}{c}\text { Time fin- } \\
\text { ished being } \\
\text { served of } \\
\text { payment }\end{array}$ \\
\hline \multirow{12}{*}{ 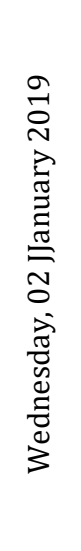 } & 1 & 07:28:45 & 07:50:05 & 07:52:09 & 07:53:09 & 07:55:54 & $07: 56: 54$ & 07:58:23 \\
\hline & 2 & $07: 29: 24$ & 07:53:00 & $07: 55: 45$ & $07: 55: 54$ & $07: 57: 23$ & 07:58:23 & 08:00:08 \\
\hline & 3 & 07:29:39 & 07:56:50 & 07:58:19 & 07:58:23 & 08:00:08 & 08:00:18 & 08:02:43 \\
\hline & 4 & 07:30:07 & 07:58:23 & 08:00:08 & 08:01:00 & 08:03:25 & 08:05:33 & 08:07:54 \\
\hline & 5 & $07: 30: 47$ & 08:01:05 & 08:03:30 & 08:03:33 & 08:05:54 & 08:07:54 & 08:09:35 \\
\hline & 6 & 07:31:03 & 08:05:33 & 08:07:54 & 08:07:54 & 08:09:35 & 08:09:35 & 08:11:42 \\
\hline & 7 & 07:31:31 & 08:07:54 & 08:09:35 & 08:09:35 & 08:11:42 & 08:11:42 & 08:13:53 \\
\hline & 8 & 07:31:59 & 08:09:35 & 08:11:42 & 08:11:42 & 08:13:53 & 08:13:53 & $08: 15: 21$ \\
\hline & 9 & 07:32:18 & 08:11:42 & 08:13:53 & 08:13:53 & 08:15:21 & 08:15:21 & 08:17:30 \\
\hline & 10 & 07:32:40 & 08:13:53 & $08: 15: 21$ & 08:15:21 & 08:17:30 & 08:17:30 & 08:19:05 \\
\hline & $\ldots$ & $\ldots$ & $\ldots$ & $\ldots$ & $\ldots$ & $\ldots$ & $\ldots$ & $\ldots$ \\
\hline & 168 & 11:59:39 & $14: 06: 24$ & $14: 09: 31$ & $14: 09: 31$ & $14: 12: 56$ & $14: 12: 56$ & $14: 15: 40$ \\
\hline
\end{tabular}

Table 2. Observation data for time of arrival, service start time, and service finished time of five years tax payments

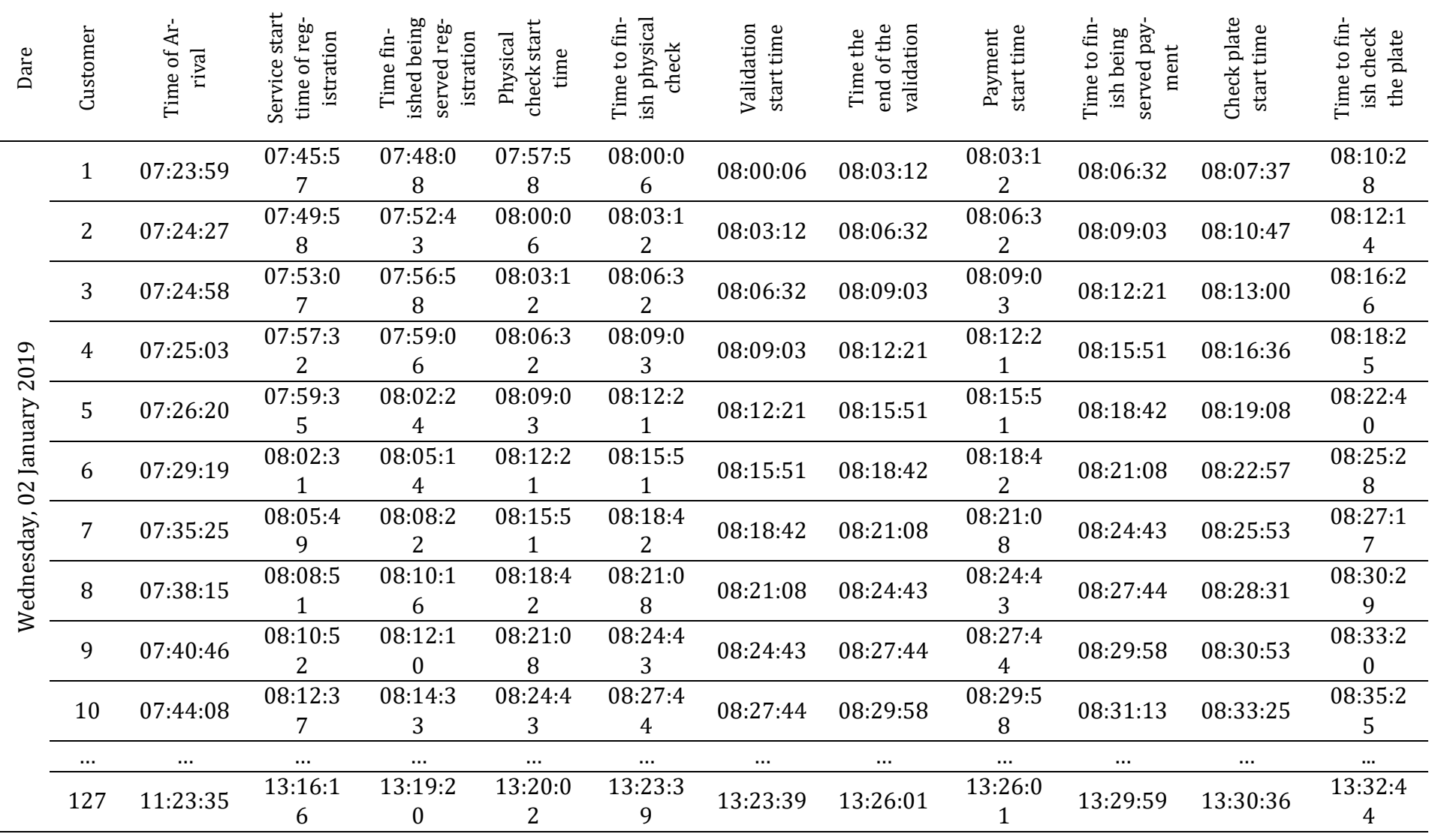




\section{Data Processing}

At the data processing stage, first, the cumulative probabilistic distribution value of the time between arrivals and service times is sough, then random number generation is carried out. After generating random numbers, they are used as initial data to simulate queues. Then experimental simulation is performed. Next, a comparison is made between the simulation results and the real situation with the number of different officers (suggestions).

After generating random numbers and new data for the time between arrivals, registration service time, validation, and payment are obtained, then an experimental simulation is carried out.

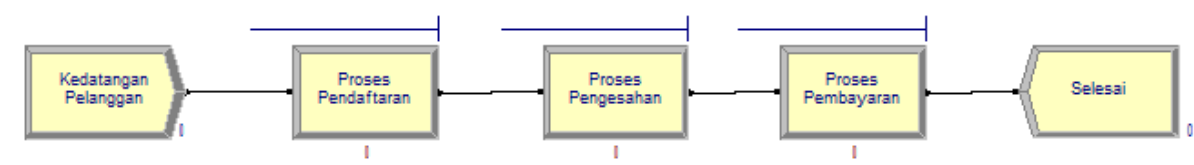

Figure 1. Design of the initial model system for annual tax payments in arena

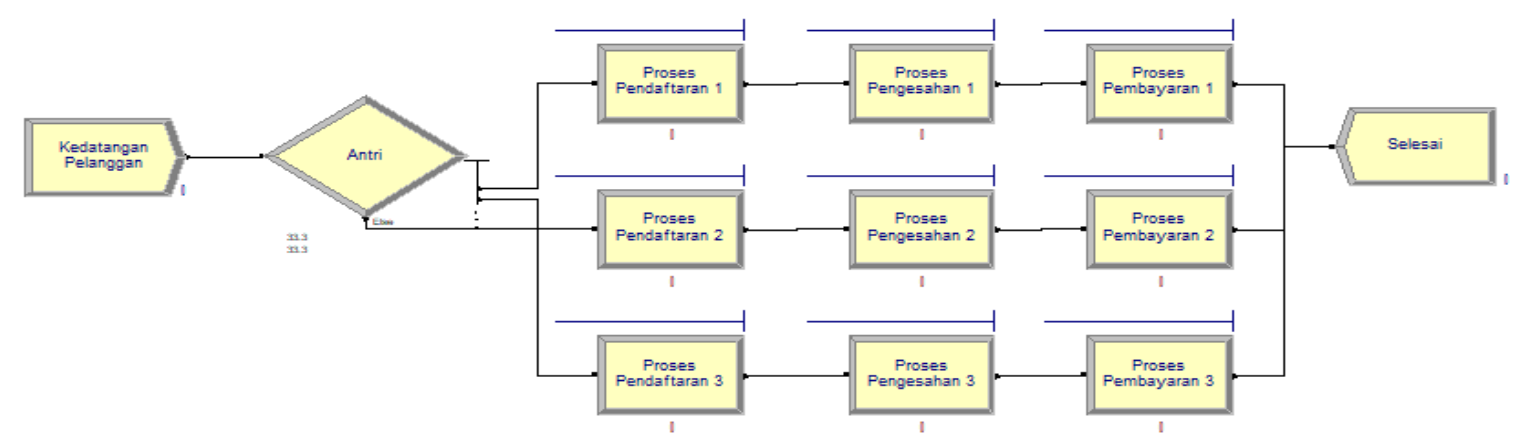

Figure 2. Design of the proposed model system with 3 officers in arena

Based on the design of the proposed model system, the simulation output results are obtained as follows.

Table 3. The output results of utility, waiting time, and queue length for annual tax payments with 3 service officers

\begin{tabular}{|c|c|c|c|c|c|c|c|c|c|}
\hline \multirow[b]{2}{*}{ Date } & \multicolumn{3}{|c|}{ Utility (\%) } & \multicolumn{3}{|c|}{ Waiting time (minute) } & \multicolumn{3}{|c|}{ Queue Length (person) } \\
\hline & server 1 & server 2 & server 3 & $\begin{array}{c}\text { Waiting } \\
\text { time1 }\end{array}$ & $\begin{array}{c}\text { Waiting } \\
\text { time } 2\end{array}$ & $\begin{array}{c}\text { Waiting } \\
\text { time } 3\end{array}$ & $\begin{array}{c}\text { Queue } \\
\text { length1 }\end{array}$ & $\begin{array}{c}\text { Queue } \\
\text { length } 2\end{array}$ & $\begin{array}{c}\text { Queue } \\
\text { length } 3\end{array}$ \\
\hline $2 / 01 / 2019$ & 0.90284 & 0.84962 & 0.83156 & 12.1476 & 12.3262 & 19.2111 & 1.68338 & 1.55591 & 2.48052 \\
\hline $3 / 01 / 2019$ & 0.93203 & 0.98241 & 0.99844 & 36.099 & 103.535 & 73.955 & 4.9737 & 13.6291 & 10.0178 \\
\hline $4 / 01 / 2019$ & 0.75463 & 0.9491 & 0.75443 & 7.0572 & 21.6489 & 9.0374 & 0.76453 & 2.9031 & 0.99802 \\
\hline $5 / 01 / 2019$ & 0.84174 & 0.97862 & 0.67627 & 21.4867 & 43.138 & 22.9872 & 2.49067 & 5.7603 & 2.67544 \\
\hline $7 / 01 / 2019$ & 0.87835 & 0.86505 & 0.86886 & 29.7988 & 14.7161 & 9.7498 & 3.7516 & 1.74919 & 1.20732 \\
\hline $8 / 01 / 2019$ & 0.82846 & 0.78068 & 0.76987 & 36.836 & 13.4713 & 11.1623 & 4.122 & 1.43175 & 1.16275 \\
\hline $9 / 01 / 2019$ & 0.94056 & 0.93444 & 0.93382 & 19.268 & 23.1932 & 28.9062 & 2.28862 & 2.6606 & 3.3595 \\
\hline $10 / 01 / 2019$ & 0.98742 & 0.9026 & 0.96641 & 77.75 & 17.5883 & 45.349 & 9.494 & 1.86014 & 5.4189 \\
\hline $11 / 01 / 2019$ & 0.90344 & 0.62957 & 0.8838 & 21.916 & 5.3922 & 24.5957 & 2.14367 & 0.39231 & 2.37782 \\
\hline $12 / 01 / 2019$ & 0.79827 & 0.66845 & 0.67222 & 21.2521 & 12.9494 & 16.1217 & 2.06495 & 0.99819 & 1.27943 \\
\hline $14 / 01 / 2019$ & 0.78695 & 0.95297 & 0.69343 & 11.2903 & 64.917 & 7.8133 & 0.96439 & 6.8473 & 0.60441 \\
\hline $15 / 01 / 2019$ & 0.75424 & 0.79085 & 0.81334 & 11.4381 & 12.8529 & 10.4961 & 0.96147 & 1.16457 & 1.01617 \\
\hline $16 / 01 / 2019$ & 0.54225 & 0.92151 & 0.81638 & 3.26508 & 46.284 & 31.2751 & 0.18366 & 4.1363 & 2.59769 \\
\hline
\end{tabular}


Table 4. The output results of utility, waiting time, and queue length for five years tax payments with 3 service officers

\begin{tabular}{|c|c|c|c|c|c|c|c|c|c|}
\hline \multirow[b]{2}{*}{ Date } & \multicolumn{3}{|c|}{ Utility (\%) } & \multicolumn{3}{|c|}{ Waiting time (minute) } & \multicolumn{3}{|c|}{ Queue Length (person) } \\
\hline & server 1 & server 2 & Server 3 & $\begin{array}{c}\text { Waiting } \\
\text { time } 1\end{array}$ & $\begin{array}{l}\text { Waiting } \\
\text { time } 2\end{array}$ & $\begin{array}{c}\text { Waiting } \\
\text { time } 3\end{array}$ & $\begin{array}{c}\text { Queue } \\
\text { length 1 }\end{array}$ & $\begin{array}{c}\text { Queue } \\
\text { legnth 2 }\end{array}$ & $\begin{array}{c}\text { Queue } \\
\text { length } 3\end{array}$ \\
\hline $17 / 01 / 2019$ & 0.86276 & 0.7492 & 0.9464 & 16.4872 & 7.0294 & 34.823 & 1.51821 & 0.59065 & 3.3538 \\
\hline $18 / 01 / 2019$ & 0.84548 & 0.84559 & 0.80174 & 18.8162 & 24.1194 & 14.4257 & 1.79785 & 2.51622 & 1.34166 \\
\hline $19 / 01 / 2019$ & 0.97264 & 0.90968 & 0.92161 & 30.935 & 37.89 & 42.755 & 3.7081 & 4.1049 & 4.5434 \\
\hline $21 / 01 / 2019$ & 0.85529 & 0.69382 & 0.91041 & 16.8944 & 6.0296 & 30.105 & 1.53013 & 0.43967 & 2.94619 \\
\hline $22 / 01 / 2019$ & 0.87521 & 0.70854 & 0.71238 & 14.6295 & 10.3817 & 9.4473 & 1.30013 & 0.77542 & 0.70099 \\
\hline $23 / 01 / 2019$ & 0.82101 & 0.85581 & 0.82465 & 35.502 & 22.7542 & 21.9812 & 3.1065 & 2.13322 & 2.10907 \\
\hline $24 / 01 / 2019$ & 0.96731 & 0.71411 & 0.54885 & 17.071 & 12.9717 & 2.95458 & 1.81 & 1.08494 & 0.19977 \\
\hline $25 / 01 / 2019$ & 0.82744 & 0.94972 & 0.70963 & 30.657 & 55.559 & 8.7149 & 3.19482 & 5.9096 & 0.69487 \\
\hline $26 / 01 / 2019$ & 0.88729 & 0.58702 & 0.71594 & 36.359 & 4.29014 & 20.1699 & 3.7873 & 0.3039 & 1.8069 \\
\hline $28 / 01 / 2019$ & 0.78714 & 0.74205 & 0.68687 & 26.9241 & 12.5355 & 23.7858 & 2.2914 & 1.03846 & 1.84936 \\
\hline $29 / 01 / 2019$ & 0.74643 & 0.82921 & 0.73048 & 15.2087 & 17.4448 & 6.9361 & 1.11345 & 1.39066 & 0.47561 \\
\hline $30 / 01 / 2019$ & 0.67408 & 0.83092 & 0.58637 & 14.3735 & 16.5196 & 7.1967 & 1.08982 & 1.38735 & 0.44416 \\
\hline $31 / 01 / 2019$ & 0.72557 & 0.6899 & 0.5786 & 7.1441 & 7.7912 & 6.8487 & 0.55071 & 0.60087 & 0.42256 \\
\hline Mean & & 0.8123 & & & 22.5479 & & & 2.3863 & \\
\hline
\end{tabular}

After the simulation is complete, a comparison is made between the real system simulation results and the simulation results for annual and five years of taxes.

Table 5. Recapitulation of comparison between real system waiting time and simulation result waiting time on annual tax payments

Mean waiting time (minute)

The number servants scenario

$$
\text { Real system }
$$

Simulation results for each sce-

nario

\begin{tabular}{lcc}
\hline 1 & 103.82 & 148.2562 \\
\hline 2 & - & 67.5106 \\
\hline 3 & - & 22.5479 \\
\hline
\end{tabular}

Table 6. Recapitulation of comparison between real system waiting time and simulation result waiting time on five years tax payments

The number of servants scenario

Mean waiting time (minute)

\begin{tabular}{ccc}
\cline { 2 - 3 } & Real system & $\begin{array}{c}\text { Simulation results for each } \\
\text { scenario }\end{array}$ \\
\hline 1 & 90.25 & 113.49 \\
\hline 2 & - & 42.85336 \\
\hline
\end{tabular}

\section{Result and Discussion}

\section{Annual tax payment}

Based on the comparison between the real system and the simulations that have been carried out, which is in table 5, it is found that the optimal number of officers for annual tax payments so that the average waiting time following company policy is 3 service officers with an average waiting time of $22.5479 \approx 23$ minutes. Meanwhile, the addition of officers can be done by asking 3 officers in the data recapitulation section and 2 officers in the data checking section where work overload has not yet occurred to assist in the annual tax service process. Furthermore, there will be recruitment for annual tax service officers. 


\section{Five years of tax payment}

Based on the comparison between the real system and the simulations that have been carried out in table 6, it is found that the optimal number of officers for five years tax payments so that the average waiting time is following company policy, which is a maximum of 45 minutes, is 2 service officers with an average waiting time of $42.854 \approx 43$ minutes. Meanwhile, the addition of officers can be done by asking 3 officers in the transfer service department where work overload has not yet occurred to assist the five years tax service process. Furthermore, there will be recruitment for five years of tax service officers.

\section{Conclusion}

From the results of the discussion, it can be concluded that the optimal number of service officers for annual tax payments is 3 service officers with an average waiting time of $22.5479 \approx 23$ minutes, an average utility level of service officers of $81.23 \%$, and queue length of $2.3863 \approx 3$ persons. As for the five years tax payment, the optimal number of service officers is 2 officers with an average waiting time of $42.85336 \approx 43$ minutes, an average utility level of service officers of $91.38 \%$, and queue length of $4.55057 \approx 5$ persons.

\section{Acknowledgment}

This work was financially supported by Industrial Engineering Department and Chemical Engineering Department, Universitas Pembangunan Nasional "Veteran". Therefore, we are grateful for this funding and support of this research.

\section{References}

Ariyani E. (2010). Penelitian operasional. Klaten: Yayasan Humaniora.

Blackstone, Jr. J. H., et al. (1989). Computer simulation. John Wiley and Sons, 2ed.p.63

Fadjar, A. (2008). Aplikasi simulasi Monte Carlo dalam estimasi biaya proyek. SMARTek, 6(4). ISSN :1693-0460

Ginting P.L. (2014). Analisis sistem antrian dan optimasi laayanan teller. Jurnal Manajemen Universitas Diponegoro. https://doi.org/10.14710/jsmo.v11i1.13162

Kelton, W. D., et al. (1998). Simulation with arena. Boston: McGraw Hill. 363-381

Kwak, Y. H., \& Ingall, L. (2007). Exploring monte carlo simulation applications for project management. Risk Management, 9, 44-57.

Law. A. W., et al. (2000). Simulation modelling and analysis. New York: John Willey \& Sons.

Magdalena. (2011). Simulasi antrian dengan menggunakan metode Monte Carlo. Tugas Akhir Mahasiswa Matematika Universitas Sumatra Utara.

Mulyono, S. (2017). Riset operasi. Jakarta: Mitra Wacana Media.

Tersine, R. J. (1988). Principles of inventory and materials management. North-Holland. 3ed. p.476-479 